al-Uqud: Journal of Islamic Economics

Volume 1 Nomor 1, Januari 2017

E-ISSN 2548-3544, P-ISSN 2549-0850

Halaman 14-26

\title{
POTENSI DAN REALISASI DANA ZAKAT INDONESIA
}

\author{
Clarashinta Canggih*, Khusnul Fikriyah, Ach. Yasin \\ Universitas Negeri Surabaya
}

\begin{abstract}
This paper aims to find out illustration and estimation of zakat potency as well as the amount of zakat collection in Indonesia. Furthermore, it aims to outline the diversity between potency and realization of zakat. It used quantitative descriptive approach through secondary data collection from several sources. The result shows both potency and realization of zakat collection in Indonesia were increasing during 2011-2015. However, the amount of zakat potency surpasses the amount of zakat realization with wide gap. It shows that the average amount of zakat collection on 2011-2015 is less than 1\% compare to its potency. One of the possible reason is most of Indonesian prefer to distribute their zakat directly to the muzakki, hence it is unrecorded.
\end{abstract}

Keywords: Zakat, Potency, Collection

\begin{abstract}
Abstrak
Penelitian ini bertujuan untuk mengetahui gambaran potensi zakat dan juga realisasi penerimaan zakat di Indonesia. Lebih lanjut, penelitian ini bertujuan untuk melihat perbedaan antara potensi dan realisasi penerimaan zakat. Penelitian ini menggunakan pendekatan kuantitatif deskriptif dengan pengumpulan data sekunder dari berbagai sumber. Hasil penelitian ini menunjukkan bahwa potensi dan realisasi penerimaan zakat di Indonesia mengalami peningkatan selama periode 2011-2015. Namun demikian, terdapat ketimpangan yang sangat besar antara nilai potensi dengan besaran realisasi. Selama tahun 2011-2015 realisasi penerimaan zakat hanya kurang dari 1\%. Salah satu kemungkinan adalah mayoritas orang Indonesia lebih memilih untuk menyalurkan zakat mereka langsung kepada muzakki, sehingga tidak tercatat.
\end{abstract}

Kata Kunci: Zakat, Potensi, Penerimaan

Received: 20 Desember 2016; Accepted: 04 Januari 2017; Published: 15 Januari 2017

*Korespondensi: Program Studi Ekonomi Islam, Fakultas Ekonomi, Universitas Negeri Surabaya,

Jl. Ketintang Surabaya, 60231. Email: clarashintacanggih@unesa.ac.id 


\section{PENDAHULUAN}

Kemiskinan merupakan masalah klasik yang belum terselesaikan di Indonesia sampai saat ini. Berdasarkan data dari Badan Pusat Statistik (BPS), dalam periode 20142015, terjadi peningkatan jumlah penduduk yang hidup di bawah garis kemiskinan sebesar 3\% yakni dari 27,73 juta jiwa per September 2014 menjadi 28, 51 juta jiwa per September 2015 (BPS, 2016). Alokasi Anggaran Pendapatan dan Belanja Negara Perubahan (APBN-P) tahun 2015 untuk pengentasan kemiskinan dari Kementerian Sosial sebesar $\mathrm{Rp} 14$ triliun belum memberikan dampak signifikan terhadap penurunan jumlah penduduk yang hidup di bawah garis kemiskinan (Kemsos, 2015).

Salah satu upaya dalam menurunkan angka kemiskinan di Indonesia adalah dengan melakukan pemerataan pendapatan antara golongan berkemampuan dengan golongan tidak mampu. Upaya pemerataan pendapatan yang dikenal dalam Islam salah satunya adalah zakat. Zakat dapat diartikan sebagai al-barakatu (keberkahan), al-namaa (pertumbuhan dan perkembangan), at-thaharatu (kesucian), as-salahu (keberesan), dan terpuji (Qardhawi, 1999; Hafidhuddin, 2006). Secara teknis, zakat merupakan sejumlah uang atau barang yang diambil dari harta yang telah memenuhi syarat haul dan nisab dan diserahkan kepada muzakki (Zulkifli, 2011). Zakat merupakan salah satu pilar dalam rukun Islam sebagai bentuk tindakan sosial yang wajib dilakukan oleh setiap Muslim. Kewajiban tersebut disebutkan dalam Al Qur'an berulang kali bersandingan dengan kewajiban menunaikan sholat (Muhammad, Saad, 2016). Zakat menyucikan jiwa dari kekikiran, ketamakan, dan keegoisan; menyucikan harta dari hak orang lain; serta berdampak positif pada perekonomian masyarakat dengan mengurangi kemiskinan meningkatkan pertumbuhan ekonomi, dan meningkatkan purchasing power parity ( Permono 2005; Abu Bakar dan Abdul Rahim, 2011; Syahrullah dan Ulfah, 2016). Zakat merupakan bentuk ibadah bernilai sosial dan ekonomi yang dapat memperkecil kesenjangan ekonomi dalam masyarakat. Dengan pengelolaan zakat yang tepat diharapkan distribusi kekayaan yang merata dapat diwujudkan. 
Zakat dapat dibagi menjadi dua jenis, zakat fitrah dan zakat maal. Zakat fitrah dibayarkan saat bulan Ramadhan atas setiap individu sedangkan zakat maal dikeluarkan atas harta yang dimiliki. Adapun syarat-syarat kekayaan yang wajib dizakati adalah: 1) Milik Penuh (Almilkuttam), 2) Berkembang, 3) Cukup Nishab, 4) Lebih Dari Kebutuhan Pokok (Alhajatul Ashliyah), 5) Bebas dari hutang, dan 6) Berlalu Satu Tahun (Al-Haul) (Qardhawi, 1999). Jenis kekayaan yang dapat menjadi obyek pembayaran zakat maal dapat dibedakan menjadi dua yakni kekayaan dalam konteks tradisional (hasil pertanian, sumber daya mineral, emas, perhiasan, uang tunai, hasil usaha, dan hewan ternak) dan kekayaan dalam konteks modern (pendapatan dari asset, gaji, surat berharga) (Abu Bakar, 2007; Qardawi, 1999).

Indonesia merupakan negara dengan penduduk Muslim terbesar di dunia. Pada tahun 2013 jumlah penduduk Muslim Indonesia mencapai 87.21\% (Kemenag, 2013). Dapat dipastikan dengan jumlah penduduk Muslim terbesar, Indonesia juga memiliki potensi zakat yang besar. Berdasarkan penelitian Baznas, Institut Pertanian Bogor (IPB), dan Islamic Development Bank (IDB), potensi zakat nasional sebesar Rp 217 triliun. Angka tersebut harusnya dapat berdampak luar biasa dalam upaya pengentasan kemiskinan di Indonesia. Namun demikian laporan BAZNAS mengungkapkan bahwa dari potensi zakat tersebut yang bisa terserap dan dikelola oleh lembaga BAZNAS baru mencapai Rp. 450 Milyar untuk tahun 2007, meningkat menjadi Rp 2,73 triliun pada tahun 2013 atau hanya sekitar 1\% saja.

Sejauh ini penelitian tentang zakat membahas mengenai potensi zakat, dampak zakat terhadap kesejahteraan masyarakat dan masalah sosial lainnya, ataupun studi tentang realisasi penerimaan dana zakat secara terpisah. Kahf (1987) mengestimasi potensi zakat pada delapan negara Islam yaitu Mesir, Indonesia, Pakistan, Qatar, Saudi Arabia, Sudan, Syria, dan Turki. Studi tersebut melakukan estimasi zakat dengan tiga cara: 1) berdasarkan fikih tradisional, 2) berdasarkan perhitungan dari Qardawi yakni zakat pendapatan dihitung 2.5\% sedangkan keuntungan bersih pada aset tetap dihitung 10\%, dan 3) modifikasi dari versi Qardawi yakni seluruh zakat baik dari aset tetap dan pendapatan dihitung sama sebesar $2.5 \%$. Hasil penelitian 
tersebut menunjukkan bahwa potensi zakat di Indonesia berkisar antara 1 sampai 2 persen dari PDB.

Studi yang dilakukan oleh PIRAC pada tahun 2004 mengestimasikan potensi zakat di Indonesia mencapai Rp. 6.132 triliun (Kurniawati, 2004). Sementara itu Firmansyah (2009) mengestimasikan potensi zakat dengan menggunakan asumsi kadar zakat minimal 2,5 \% dari masing-masing sektor ekonomi daerah (PDRB) seperti berikut: 1) Kadar zakat pertanian adalah 2,5\% dari nilai PDRB sektor pertanian; 2) Kadar zakat pertambangan adalah 2,5\% dari nilai PDRB sektor pertambangan; 3) Kadar zakat sektor lainnya adalah masing-masing 2,5\%. Studi yang dilakukan oleh Firdaus dkk (2012) menunjukkan total seluruh potensi zakat di Indonesia dari berbagai sumber yakni pendapatan rumah tangga, pendapatan perusahaan, dan tabungan diestimasikan sebesar Rp. 217 triliun atau setara dengan 3.4\% PDRB Indonesia tahun 2010.

Dalam studi yang dilakukan Mukhlis dan Beik (2013) disebutkan bahwa dana zakat yang diterima oleh BAZ Kabupaten Bogor selalu mengalami kenaikan dengan nilai yang cukup besar pada periode 2006-2010. Dana zakat maal yang diperoleh oleh BAZ kabupaten Bogor pada tahun 2010 mencapai Rp. 1.5 Milyar, yang mengalami peningkatan sebesar $119 \%$ jika dibandingkan tahun 2006. Sementara itu data yang dihimpun oleh BAZNAS, pada tahun 2014 realisasi penerimaan zakat di Indonesia adalah sebesar Rp. 3.2 trilyun (Sitorus, 2015).

Namun demikian, sejauh ini belum ditemukan penelitian yang melihat dan membandingkan trend potensi dan realiasi penerimaan dana zakat. Oleh karena itu penelitian ini bertujuan untuk mengestimasi besaran potensi penerimaan dana zakat utamanya zakat maal di Indonesia untuk kemudian dibandingkan dengan realisasi penerimaan dana zakat maal di Indonesia.

\section{METODE PENELITIAN}

Penelitian ini merupakan penelitian deskriptif karena mendeskripsikan atau menggambarkan tentang potensi dan realisasi penerimaan zakat di Indonesia. Adapun 
pendekatan penelitian yang digunakan adalah pendekatan kuantitatif. Objek penelitian ini adalah potensi dan realisasi penerimaan zakat di Indonesia. Subjek pada penelitian ini adalah penerimaan zakat dari masyarakat Indonesia. Dalam penelitian ini lebih spesifik kepada zakat maal atau zakat atas harta, terutama zakat atas pendapatan, karena zakat fitrah umumnya diserahkan langsung dari muzakki kepada mustahiq tanpa campur tangan lembaga zakat dan memiliki batasan waktu pengumpulan dan penyaluran.

Dalam penelitian ini teknik pengumpulan data yang digunakan adalah teknik dokumentasi. Teknik dokumentasi digunakan untuk memperoleh data sekunder mengenai data potensi penerimaan zakat dan data realisasi penerimaan zakat. Data potensi penerimaan zakat menggunakan data jumlah angkatan kerja yang bekerja, presentase penduduk muslim dan data pendapatan per kapita masyarakat Indonesia. Data tersebut diperoleh dari Badan Pusat Statistik (BPS), Kementerian Agama, Badan Amil Zakat Nasional (BAZNAS), dan juga Lembaga Amil Zakat Nasional (LAZNAS) pada tahun 2011-2015.

Analisis deskriptif dilakukan untuk memperoleh gambaran potensi penerimaan zakat dan realisasi penerimaan zakat di Indonesia. Potensi penerimaan zakat dihitung dengan memodifikasi penghitungan potensi zakat versi Qardawi yakni hanya menghitung $2.5 \%$ dari zakat pendapatan. Pendapatan yang digunakan dalam penelitian ini adalah pendapatan per kapita penduduk Muslim yang termasuk dalam kategori angkatan kerja yang bekerja. Hasil pengukuran deskriptif tersebut kemudian akan digunakan sebagai dasar untuk memotret perbedaan antara potensi penerimaan zakat dengan realisasi penerimaan zakat di Indonesia.

\section{HASIL DAN PEMBAHASAN}

Indonesia merupakan negara dengan jumlah penduduk terbesar ke-4 di dunia. Dari total jumlah penduduk Indonesia sekitar 48\% merupakan angkatan kerja yakni penduduk usia kerja (15 tahun ke atas) yang bekerja, punya pekerjaan tapi sementara 
tidak bekerja, dan pengangguran (BPS, 2016). Dari total penduduk di Indonesia, diasumsikan yang wajib menunaikan zakat maal adalah angkatan kerja beragama Islam yang bekerja. Data estimasi penduduk yang wajib mengeluarkan zakat maal di Indonesia ditampilkan dalam tabel 4.1. Dapat dilihat bahwa rata-rata sekitar 39\% dari total penduduk Indonesia, wajib membayar zakat maal. Terjadi peningkatan jumlah penduduk yang wajib berzakat setiap tahunnya

Tabel 1. Estimasi Penduduk yang Wajib Berzakat

\begin{tabular}{ccc}
\hline Tahun & $\begin{array}{c}\text { Penduduk yang Wajib Zakat } \\
\text { Maal }\end{array}$ & $\begin{array}{c}\text { Total Penduduk } \\
\text { Indonesia }\end{array}$ \\
\hline 2011 & $95,643,555$ & $244,808,254$ \\
\hline 2012 & $96,635,791$ & $248,037,853$ \\
\hline 2013 & $96,632,204$ & $251,268,276$ \\
\hline 2014 & $99,967,101$ & $254,454,778$ \\
\hline 2015 & $100,133,823$ & $257,563,815$ \\
\hline
\end{tabular}

Sumber : Statistik Indonesia 2012-2016 (BPS), Penduduk Berdasarkan Agama (Kemenag, 2013) World Development Indicator (World Bank, 2016). Data diolah

Pendapatan per kapita mencerminkan besaran pendapatan rata-rata penduduk di suatu Negara dalam satu periode/tahun yang dijadikan acuan untuk mengukur tingkat kesejahteraan individu. Haul untuk harta yang wajib dikeluarkan zakat maal adalah satu tahun, sehingga penggunaan pendapatan per kapita dapat dijadikan sebagai gambaran nilai harta masyarakat Indonesia diukur dari sisi penghasilan. Tabel 2. mencerminkan besaran pendapatan per kapita di Indonesia periode 20112015. Dapat dilihat bahwa nilai pendapatan per kapita penduduk Indonesia mengalami peningkatan yang cukup signifikan dalam periode 2011-2015.

\begin{tabular}{cc} 
Tabel 2. Pendapatan per Kapita Indonesia \\
\hline Tahun & $\begin{array}{c}\text { Pendapatan per Kapita } \\
\text { (ribuan) }\end{array}$ \\
\hline 2011 & $21,867.70$ \\
\hline 2012 & $24,658.70$ \\
\hline 2013 & $26,527.00$ \\
\hline 2014 & $28,890.80$ \\
\hline 2015 & $31,360.30$ \\
\hline Sumber : Statistik Indonesia $2012-2016($ BPS)
\end{tabular}


Secara keseluruhan dapat diproyeksikan bahwa potensi penerimaan zakat di Indonesia cukup besar. Jika dilihat dari jumlah penduduk yang wajib berzakat yang mengalami peningkatan setiap tahun dan juga pendapatan per kapita yang nominalnya juga cukup besar dan meningkat setiap tahun maka potensi penerimaan zakat juga diestimasikan mengalami peningkatan.

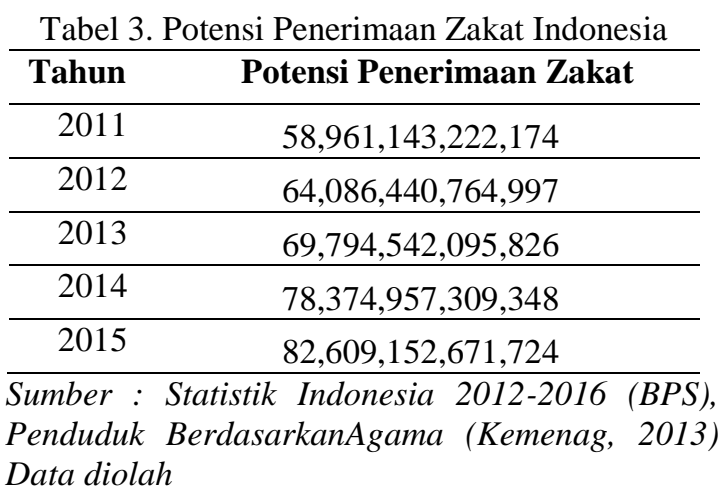

Zakat dapat disalurkan langsung dari mustahiq kepada muzakki atau melalui lembaga amil. Untuk zakat fitrah, umumnya disalurkan langsung kepada muzakki dikarenakan waktu penerimaan dan pendistribusian yang terbatas dan diutamakan langsung diserahkan kepada 8 asnaf yang berhak. Adapun untuk zakat maal, pembayaran dan pendistribusian tidak terbatas pada waktu dan tempat sehingga umumnya dapat disalurkan untuk dikelola dan didistribusikan oleh lembaga amil zakat kepada muzakki.

Nominal penerimaan zakat dapat dilihat dari beberapa hal, salah satunya adalah laporan keuangan yang dipublikasikan oleh lembaga amil zakat yang menerima, mengelola, dan mendistribusikan dana. Berikut adalah penerimaan zakat yang dipublikasikan oleh Badan Amil Zakat Nasional (BAZNAS) periode 2011-2015. 
Tabel 4. Realisasi Penerimaan Zakat Indonesia

\begin{tabular}{cc}
\hline Tahun & Realisasi Penerimaan Zakat \\
\hline 2011 & $32,986,949,797$ \\
\hline 2012 & $40,387,972,149$ \\
\hline 2013 & $50,741,735,215$ \\
\hline 2014 & $69,865,506,671$ \\
\hline 2015 & $74,225,748,204$
\end{tabular}

Sumber: Laporan Penerimaan Zakat Badan Amil Zakat Nasional 2011-2015

Dari hasil perhitungan potensi dan realisasi penerimaan zakat tersebut dapat dilihat pada gambar 1 berikut terjadi ketimpangan yang cukup signifikan antara potensi penerimaan zakat dengan realisasi dana zakat yang diterima.

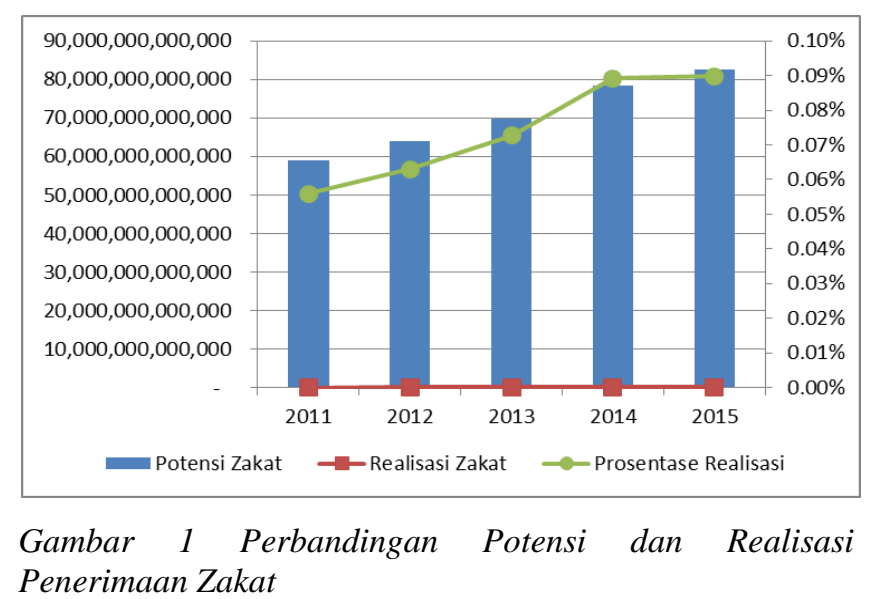

Meskipun dana zakat yang diterima setiap tahun mengalami peningkatan namun nilainya kurang dari $1 \%$ dari besaran potensi zakat sepanjang periode 20112015. Hal ini selaras dengan pendapat Khamis dkk (2014) yang menyatakan bahwa mayoritas orang Muslim sangat memperhatikan pembayaran zakat fitrah, namun tidak untuk zakat pendapatan atau zakat maal.

Ketimpangan antara potensi zakat dan realisasi zakat yang diterima bertolak belakang dengan fakta bahwa Indonesia merupakan negara dengan penduduk Muslim terbesar di dunia, dengan hampir $87.5 \%$ penduduk Muslim. Ketimpangan antara potensi dan realisasi zakat berkisar pada $0.06 \%$ pada tahun 2011, 0.068\% pada tahun 
2012, $0.075 \%$ pada tahun $2013,0.089 \%$ pada tahun 2014 , dan $0,09 \%$ pada tahun 2015. Siswantoro dan Nurhayati (2012) dan Mukhlis dan Beik (2013) menyebutkan bahwa mayoritas penduduk Muslim di Indonesia masih enggan dan kurang termotivasi untuk membayar zakat, terutama zakat maal.

Salah satu kemungkinan utama adanya ketimpangan tersebut adalah realitas bahwa masih banyak muzaki di Indonesia yang membayarkan zakatnya tanpa melalui lembaga zakat, namun langsung kepada mustahiq sehingga hal tersebut menyebabkan pembayaran data dari muzaki tidak terdata oleh pengelola zakat (Uzaifah 2007:135, Infoz 2011:21, Huda dan Sawarjuwono:2013). Rendahnya kepercayaan masyarakat terhadap lembaga pengelola zakat juga dapat menjadi penyebab kesenjangan antara besaran potensi zakat dan nominal zakat yang diterima. Profesionalisme lembaga zakat dan hasil pengelolaan zakat yang tidak terpublikasi kepada masyarakat luas adalah hal yang membuat kepercayaan masyarakat rendah terhadap lembaga pengelola zakat (Hafiduddin;2011, Wahid dkk;2009). Hal ini menunjukkan kepatuhan masyarakat dalam membayar zakat berbanding lurus dengan peran dari institusi pengelola zakat. Peningkatan profesionalisme lembaga zakat, melalui peningkatan mutu pelayanan dalam hal transparansi pengelolaan, sosialisasi, dan administrasi, akan meningkatkan preferensi masyarakat untuk membayar zakat melalui lembaga tersebut dan dampaknya akan dapat meningkatkan kepatuhan muzakki dalam membayar zakat (Mukhlis dan Beik;2013).

Jika kepatuhan muzakki untuk membayar zakat mengalami peningkatan dan preferensi terhadap lembaga zakat semakin tinggi, maka muzakki akan lebih banyak membayarkan zakatnya melalui lembaga zakat. Dengan makin banyaknya muzakki yang membayar zakat melalui lembaga zakat, hal itu akan tercatat oleh institusi pengelola zakat, penerimaan zakat bisa meningkat seiring dengan potensi zakat yang cukup besar di Indonesia. Sebagai upaya untuk peningkatan penerimaan zakat, perlu adanya tindakan dan langkah yang nyata untuk dapat mempengaruhi orang untuk membayar zakat terutama melalui lembaga zakat. Dengan membayar zakat melalui lembaga zakat, pendayagunaan zakat akan lebih optimal jika dibandingkan dengan 
membayar secara langsung kepada mustahiq (Huda, Sawarjuwono;2013). Upaya untuk mempengaruhi orang dapat dilakukan dalam banyak sarana antara lain dengan menyediakan informasi yang sesuai dan selalu update, seminar, kampanye, dan juga diskusi terbuka tentang isu-isu terkini dari zakat (Syahrullah dan Ulfah;2016).

Upaya untuk mempengaruhi muzakki agar membayar zakat melalui lembaga zakat juga dapat diterapkan untuk meningkatkan pemahaman muzakki akan kewajiban zakat. Salah satu penyebab rendahnya zakat yang dihimpun juga disebabkan oleh rendahnya pemahaman kewajiban zakat oleh muzakki (IMZ dan PEBS:2009, Infoz:2011, Syahrullah dan Ulfah:2016). Edukasi tentang kewajiban zakat menjadi sebuah keharusan untuk meningkatkan penerimaan zakat. Namun demikian dalam melakukan edukasi tentang zakat tidak hanya menekankan kepada aspek keagamaan. Mukhlis dan Beik (2013) menyatakan bahwa kepatuhan seseorang dalam membayar zakat bukan hanya dilandasi oleh faktor keagamaan, keimanan, pemahaman tentang ilmu agama dan juga tentang pahala dan dosa, namun juga tentang kepedulian sosial dan kepuasaan diri. Sehingga setiap muzakki seharusnya diberikan edukasi tentang pentingnya membayar zakat dari segi spiritual, ekonomi dan juga tanggung jawab sosial terutama bagi masyarakat yang membutuhkan (Syahrullah dan Ulfah, 2016) dalam upaya peningkatan penerimaan dana zakat.

Selain itu pemerintah juga berperan penting dalam upaya peningkatan pembayaran zakat di masyarakat. Salah satunya dengan kebijakan zakat sebagai pengurang pajak. Bank Indonesia juga menginisiasi penyusunan standardisasi zakat internasional untuk meningkatkan pengumpulan penerimaan zakat dan mengoptimalkan pengelolaan zakat sesuai best practices.

\section{PENUTUP}

Potensi dan realisasi dana zakat di Indonesia pada periode 2011-2015 mengalami peningkatan sejalan dengan peningkatan jumlah penduduk yang wajib berzakat dan pendapatan per kapita. Namun demikian peningkatan penerimaan dana zakat tidak sebanding dengan dengan peningkatan potensi zakat. Terjadi kesenjangan yang 
sangat besar antara potensi dan realisasi penerimaan zakat. Rata-rata besaran dana zakat yang diterima hanya kurang dari $1 \%$ dari total potensi yang ada. Perlu adanya perhatian dan penanganan dari semua pihak yang terkait. Adanya sinergi yang baik dari pemerintah, lembaga zakat, bank sentral, dan masyarakat dapat meningkatkan penerimaan zakat di Indonesia.

\section{DAFTAR PUSTAKA}

Abu Bakar, Nur Barizah. 2007. Study Guide: Zakat Accounting Concepts and Application. Kuala Lumpur: Wise Words Publishing.

Abu Bakar, Nur Barizah dan Abdul Rashid, H.M. 2010. Motivations of Paying Zakat on Income: Evidence from Malaysia. International Journal of Economics and Finance. 2 (3): 76-84

Al Qardawi, Y., 1999. A Comparative Study of Zakah, Regulations and Philosophy in the Light of Qur'an and Sunnah. Translated by Monzer Kahf, 1 .

BAZNAS. 2015. Laporan Penerimaan Zakat Badan Amil Zakat Nasional 2015. Jakarta : BAZNAS

BAZNAS. 2014. Laporan Penerimaan Zakat Badan Amil Zakat Nasional 2014. Jakarta : BAZNAS

BAZNAS. 2013. Laporan Penerimaan Zakat Badan Amil Zakat Nasional 2013. Jakarta : BAZNAS

BAZNAS. 2012. Laporan Penerimaan Zakat Badan Amil Zakat Nasional 2012. Jakarta : BAZNAS

BAZNAS. 2011. Laporan Penerimaan Zakat Badan Amil Zakat Nasional 2011. Jakarta : BAZNAS

BPS. 2016. Statistik Indonesia 2016. Jakarta: BPS

BPS. 2015. Statistik Indonesia 2015. Jakarta: BPS

BPS. 2014. Statistik Indonesia 2014. Jakarta: BPS

BPS. 2013. Statistik Indonesia 2013. Jakarta: BPS

BPS. 2012. Statistik Indonesia 2012. Jakarta: BPS

Firdaus, Muhammad, dkk. 2012. Economic Estimation and Determinations of Zakat

Potential in Indonesia. IRTI Working Paper Series No. 1433-07. Jeddah: IRTI

Firmansyah. 2009. Potensi dan Peran Zakat Dalam Mengatasi Kemiskinan, Studi Kasus Jawa Barat dan Jawa Timur. Jakarta: LIPI. 
Forum Zakat. 2016. Forum Zakat Gelar Konferensi Zakat Nasional 2016. Berita Publikasi Forum Zakat. Tersedia di http://forumzakat.org/forum-zakat-gelarkonferensi-zakat-nasional-2016/ . Diakses pada 20 Maret 2016

Hafidhuddin, Didin. 2006. Analisis Efektifitas Promosi Lembaga Amil Zakat Dalam Penghimpunan Zakat Bagi Peningkatan Kesejahteraan Keluarga Dhuafa: Studi Kasus Lembaga Amil Zakat Dompet Dhuafa Republika. Media Gizi \& Keluarga, Juli 2006, 30(1): 100-109.

Huda, Nurul , Sawarjuwono, Tjiptohadi. 2013. Akuntabilitas Pengelolaan Zakat melalui Pendekatan Modifikasi Action Research. Jurnal Akuntansi Multiparadigma. Volume 4, Nomor 3, Desember 2013, Hlm 376-388

Indonesia Magnificence of Zakat (IMZ) dan PEBS. 2009. Indonesia Zakat and Development Report 2009: Zakat dan Era Pembangunan: Era Baru Zakat Menuju Kesejahteraan Ummat. Indonesia Zakat \& Development Report. Jakarta.

Infoz. 2011. Perlu definisi Kontekstual Mustahik. edisi 13 Tahun 6 Juli-Agustus 2011

Kahf, M. 1987. The Principle of Socio-Economic Justice in the Contemporary Fiqh of Zakah. Jeddah: IRTI -IDB . Tersedia di http://monzer.kahf.com/papers.html

Kahf, M. 1987. Zakah Estimation in Some Muslim Countries. Jeddah: IRTI -IDB. Tersedia di http://monzer.kahf.com/papers.html

Kurniawati. 2004. Kedermawanan kaum Muslimin : potensi dan realita zakat masyarakat di Indonesia. Jakarta: Piramedia (PIRAC)

Muhammad, Sam Adamu, Saad Ram Al-Jaffri. 2016. Moderating Effect of Attitude toward Zakat Payment on the Relationship between Moral Reasoning and Intention to Pay Zakat. Procedia-Social and Behavioral Sciences 219:520-527

Mukhlis,A., Beik, Irfan Syauqi. 2013. Analisis Faktor-faktor yang Memengaruhi Tingkat Kepatuhan Membayar Zakat: Studi Kasus Kabupaten Bogor. Jurnal al-Muzara'ah, Vol I, No. 1, 2013.

Permono, Sjechul Hadi. 2005. Formula Zakat Menuju Kesejahteraan Sosial. Surabaya: CV Aulia Surabaya.

Sitorus, Ropesta. 2015. Baznas Targetkan Dana Zakat 2015 sebesar Rp. 4.8 Triliun. Tersedia di: http://industri.bisnis.com/read/20150630/12/448787/baznastargetkan-dana-zakat-2015-sebesar-rp48-triliun.html. Diakses pada 20 Maret 2016

Syafa'at. 2013. Potensi Zakat, Infaq, Shodaqoh Pada Badan Amil Zakat Nasional (BAZNAS) Di Kabupaten Banyuwangi. Jurnal Penelitian. UIN Sunan Ampel. 
Syahrullah, Maria Ulfah. 2016. Response of Indonesian Academicians toward Factors Influencing the Payment of Zakat on Employment Income. Research on Humanities and Social Sciences. Vol.6, No.10, 87-94

Uzaifah. 2007. Studi Deskriptif Prilaku Dosen Perguruan Tinggi Islam DIY Dalam Membayar Zakat. La Riba Jurnal Ekonomi Islam. Vol. 1, No. 1, hal. 127-143.

Wahid, H., S. Ahmad, RA. Kader. 2009. Pengagihan Zakat oleh Institusi Zakat kepada Lapan Asnaf: Kajian di Malaysia. Working Paper disampaikan dalam Seminar Kebangsaan Ekonomi Islam 2008/09 pada 10-11 Februari 2009 di APIUM Malaysia. 